\title{
DETERMINATION OF BERYLLIUM IN VARIOUS TYPES OF NATURAL WATERS BY ELECTROTHERMAL ATOMIC ABSORPTION SPECTROMETRY
}

\author{
I. HAGAROVÁ \\ L. MACHÁČKOVÁ \\ M. ŽEMBERYOVÁ * \\ V. NÁVOJOVÁ
}

\author{
Comenius University in Bratislava \\ Faculty of Natural Sciences \\ Department of Analytical Chemistry \\ Mlynská dolina $\mathrm{CH}-2,84215$ Bratislava, Slovakia
}

Received: $16 / 09 / 11$

Accepted: 26/01/12 *to whom all correspondence should be addressed: e-mail: zemberyova@fns.uniba.sk

\begin{abstract}
The procedure for the reliable determination of $\mathrm{Be}$ in natural waters by ETAAS was elaborated. Various modifiers (EDTA, $\mathrm{Ca}\left(\mathrm{NO}_{3}\right)_{2}, \mathrm{Mg}\left(\mathrm{NO}_{3}\right)_{2}, \mathrm{Pd}\left(\mathrm{NO}_{3}\right)_{2}$ and the mixture of $\mathrm{Pd}\left(\mathrm{NO}_{3}\right)_{2}$ and $\left.\mathrm{Mg}\left(\mathrm{NO}_{3}\right)_{2}\right)$ for the determination of beryllium was examined. The applicability of the selected $\mathrm{Mg}\left(\mathrm{NO}_{3}\right)_{2}$ as the appropriate and generally used modifier for the determination of $\mathrm{Be}$ in the different types of natural waters by ETAAS has been confirmed. The accuracy of the method was verified by analyzing of the certified reference material of drinking water ("Trace Metals in Drinking Water"). The real drinking waters and waste waters with the reference values of Be concentration, spiked tap water, mineral waters and model river water were utilized for the determination of Be. Using $\mathrm{Mg}\left(\mathrm{NO}_{3}\right)_{2}$ for modification, the detection limit of $0.07 \mu \mathrm{g} \mathrm{L}^{-1}$, the quantification limit of $0.22 \mu \mathrm{g} \mathrm{L}^{-1}$ and characteristic mass of $3.7 \mathrm{pg}$ of Be were obtained. The recovery was in the range $95-111 \%$ and (\%) RSD value was less than $8 \%$.
\end{abstract}

KEYWORDS: Beryllium, ETAAS, Magnesium nitrate, Chemical modifier, Natural waters.

\section{INTRODUCTION}

Beryllium is one of the most toxic elements in the periodic table. It is responsible for the often-fatal lung disease, Chronic Beryllium Disease (CBD) or berylliosis, and is listed as a Class A EPA carcinogen (Taylor et al., 2003). Although, acute and chronic beryllium poisoning occurs mainly by the inhalation of industrial gases and dust, the determination of trace amounts of beryllium in natural waters is of interest as it can indicate environmental pollution and could provide some information of the metal uptake trough these sources. According to different national guidelines, the beryllium concentration in tap or surface water should not exceed a limit 0.1 resp. $0.2 \mathrm{\mu g} \mathrm{L}^{-1}$.

Different methods have been used for the determination of beryllium in waters. These include molecular spectrophotometry (Madrakian et al., 2005; Amin 2001; Singh et al., 1998; Chamsaz et al., 2010), spectrofluorimetry (Rama et al., 2004; Jiang and He, 2003), inductively coupled plasma atomic emission spectrometry (ICP-AES) (McAlister and Horwitz 2005; Okamoto et al., 2002; Wu et al., 2001), inductively coupled plasma mass spectrometry (ICP-MS) (Forrer et al., 2001a; Forrer et al., 2001b; Wen et al., 2000), flame atomic absorption spectrometry (FAAS) (Yamini et al., 2002; Afkhami et al., 2001; Suvardhan et al., 2006) or electrothermal atomic absorption spectrometry (ETAAS) (Peng and Kuo, 2000; Burguera et al., 1999; Sun, 1999; Recknagel et al., 1997; Korečková-Sysalová, 1997; Černohorský and Kotrlý, 1995; Kubová et al., 1994; Nakamura et al., 1994; Robles and Aller, 1994; Hiraide et al., 1994; Yang and Ni, 1994; Burguera et al., 2000; Vanhoe et al., 1988; Fangruo et al., 1990; Shan et al., 1989; Lytle et al., 1993). Among these methods, ETAAS offers relatively low cost, simplicity, high selectivity and sensitivity. In ETAAS, the use of various chemical modifiers such as magnesium nitrate (Burguera et al., 1999; KorečkováSysalová, 1997; Hiraide et al., 1994; Vanhoe et al., 1988; Fangruo et al., 1990), ammonium phosphomolybdate (Lytle et al., 1993), lanthanum nitrate (Fangruo et al., 1990), calcium nitrate (Sun 
1999; Fangruo et al., 1990), aluminium nitrate (Sun 1999; Černohorský and Kotrlý, 1995; Fangruo et al., 1990), strontium nitrate (Fangruo et al., 1990), palladium nitrate (Yang and Ni, 1994), ammonium nitrate (Kubová et al., 1994), isomorphous metals, such as Eu, Ir, Sm (Burguera et al., 1999), Lu (Burguera et al., 1999; Burguera et al., 2000) and Zr (Castro et al., 2009) have been reported for the determination of beryllium in biological and environmental samples.

In the present work, five various chemical modifiers (EDTA, $\mathrm{Ca}\left(\mathrm{NO}_{3}\right)_{2}, \mathrm{Mg}\left(\mathrm{NO}_{3}\right)_{2}, \mathrm{Pd}\left(\mathrm{NO}_{3}\right)_{2}$, and the combination of $\mathrm{Pd}\left(\mathrm{NO}_{3}\right)_{2}$ and $\left.\mathrm{Mg}\left(\mathrm{NO}_{3}\right)_{2}\right)$ were compared and the selection of the chemical modifier, suitable for all types of waters was made and applied.

\section{METHODS}

Instrumental

The determination of Be was performed on a Perkin-Elmer (Norwalk, Connecticut, USA) model 5100 PC atomic absorption spectrometer with Zeeman background correction, equipped with an HGA-700 graphite furnace and an AS-71 autosampler. Pyrolytically coated THGA graphite tubes (Perkin-Elmer, USA) with pre-inserted pyrolytic L'vov platforms were employed. Measurements were made using a Be hollow cathode lamp (Perkin-Elmer, USA) at $234.9 \mathrm{~nm}$ with a $0.7 \mathrm{~nm}$ spectral bandwidth and an operating current of $30 \mathrm{~mA}$. Modifiers were injected $(10 \mu \mathrm{L})$ after sample injection $(20 \mu \mathrm{L})$. Argon was used as a furnace sheath gas. Measurements were performed in the integrated absorbance mode. Temperature program for the determination of Be in water samples by ETAAS is shown in Table 1.

\section{Reagents and samples}

All reagents were of analytical grade. Concentrated $\mathrm{HNO}_{3}$, concentrated $\mathrm{HCl}$, standard stock solution of $1000 \mathrm{mg} \mathrm{L}^{-1}$ for $\mathrm{Be}\left(\mathrm{Be}_{4} \mathrm{O}\left(\mathrm{C}_{2} \mathrm{H}_{3} \mathrm{O}_{2}\right)_{6}\right.$ in $\left.0.5 \mathrm{~mol} \mathrm{~L}^{-1} \mathrm{HNO}_{3}\right)$, stock solution of $10 \mathrm{~g} \mathrm{~L}^{-1}$ for Pd $\left(\mathrm{Pd}\left(\mathrm{NO}_{3}\right)_{2}\right.$ in $\left.0.5 \mathrm{~mol} \mathrm{~L}^{-1} \mathrm{HNO}_{3}\right), \mathrm{Mg}\left(\mathrm{NO}_{3}\right)_{2} \cdot 6 \mathrm{H}_{2} \mathrm{O}, \mathrm{Ca}\left(\mathrm{NO}_{3}\right)_{2} \cdot 4 \mathrm{H}_{2} \mathrm{O}$, EDTA, $\mathrm{Fe}\left(\mathrm{NO}_{3}\right)_{3}, \mathrm{KCl}, \mathrm{NaCl}$, $\mathrm{CaCl}_{2} .2 \mathrm{H}_{2} \mathrm{O}$ and $\mathrm{Mg}\left(\mathrm{SO}_{4}\right)_{2} .7 \mathrm{H}_{2} \mathrm{O}$ were obtained from Merck (Darmstadt, Germany).

Certified reference material (CRM) "Trace metals in drinking water" (TMDW) with certified value of Be concentration was obtained from High-Purity Standards (Charleston, Canada). Waste waters (WW4, WW5) and drinking waters (DW4, DW5) with reference values of Be concentrations were obtained from Aslab (Water Research Institute, Praque, Czech Republic).

Deionized water (PRO-PS Labconco system, Kansas City, Kansas, USA) was used to prepare all the solutions and to rinse the previously cleaned laboratory ware.

Working standard solutions of $\mathrm{Be}\left(1-10 \mu \mathrm{g} \mathrm{L}^{-1}\right)$ were prepared by suitable dilution of the standard stock solution in $0.2 \%(\mathrm{v} / \mathrm{v}) \mathrm{HNO}_{3}$.

Modifiers were also prepared in $0.2 \%(\mathrm{v} / \mathrm{v}) \mathrm{HNO}_{3}$. Masses of the used modifiers were: $15 \mu \mathrm{g}$ of $\mathrm{Mg}\left(\mathrm{NO}_{3}\right)_{2}, 5 \mu \mathrm{g}$ of $\mathrm{Pd}, 50 \mu \mathrm{g}$ of $\mathrm{Ca}\left(\mathrm{NO}_{3}\right)_{2}, 100 \mu \mathrm{g}$ of EDTA, and $5 \mu \mathrm{g}$ of $\mathrm{Pd}+15 \mu \mathrm{g}$ of $\mathrm{Mg}\left(\mathrm{NO}_{3}\right)_{2}$ in $10 \mu \mathrm{L}$.

A model sample of synthetic river water (SRW) was prepared by dissolving $294 \mathrm{mg}$ of $\mathrm{CaCl}_{2} \cdot 2 \mathrm{H}_{2} \mathrm{O}$, $216 \mathrm{mg}$ of $\mathrm{NaCl}, 8.6 \mathrm{mg}$ of $\mathrm{MgSO}_{4} .7 \mathrm{H}_{2} \mathrm{O}, 9.5 \mathrm{mg}$ of $\mathrm{KCl}$ and $7.3 \mathrm{mg}$ of $\left(\mathrm{NH}_{4}\right)_{2} \mathrm{HPO}_{4}$ in $1 \mathrm{~L}$ of deionized water (Chakraborti et al., 1987).

Tap water (TW) was collected in our laboratory (Bratislava, Slovakia). Commercial mineral waters "Korytnica" sparkling (MWS) and "Korytnica" quiet (MWQ) were also used for analyses. Natural water samples (tap and mineral waters) were after sampling acidified by addition of $5 \mathrm{~mL}$ of $65 \%$ $(w / v)$ nitric acid to $1 \mathrm{~L}$ of water sample.

\section{RESULTS AND DISCUSSION}

\section{Temperature program optimization}

Without the addition of any modifier, Be was gradually lost at temperatures above $1100^{\circ} \mathrm{C}$. Five various modifiers (EDTA, $\mathrm{Ca}\left(\mathrm{NO}_{3}\right)_{2}, \mathrm{Mg}\left(\mathrm{NO}_{3}\right)_{2}, \mathrm{Pd}\left(\mathrm{NO}_{3}\right)_{2}$, and the combination of $\mathrm{Pd}\left(\mathrm{NO}_{3}\right)_{2}$ and $\left.\mathrm{Mg}\left(\mathrm{NO}_{3}\right)_{2}\right)$ were used and compared in this work. In the presence of these modifiers, higher pyrolysis temperatures were achieved (Figure 1). 
(A)

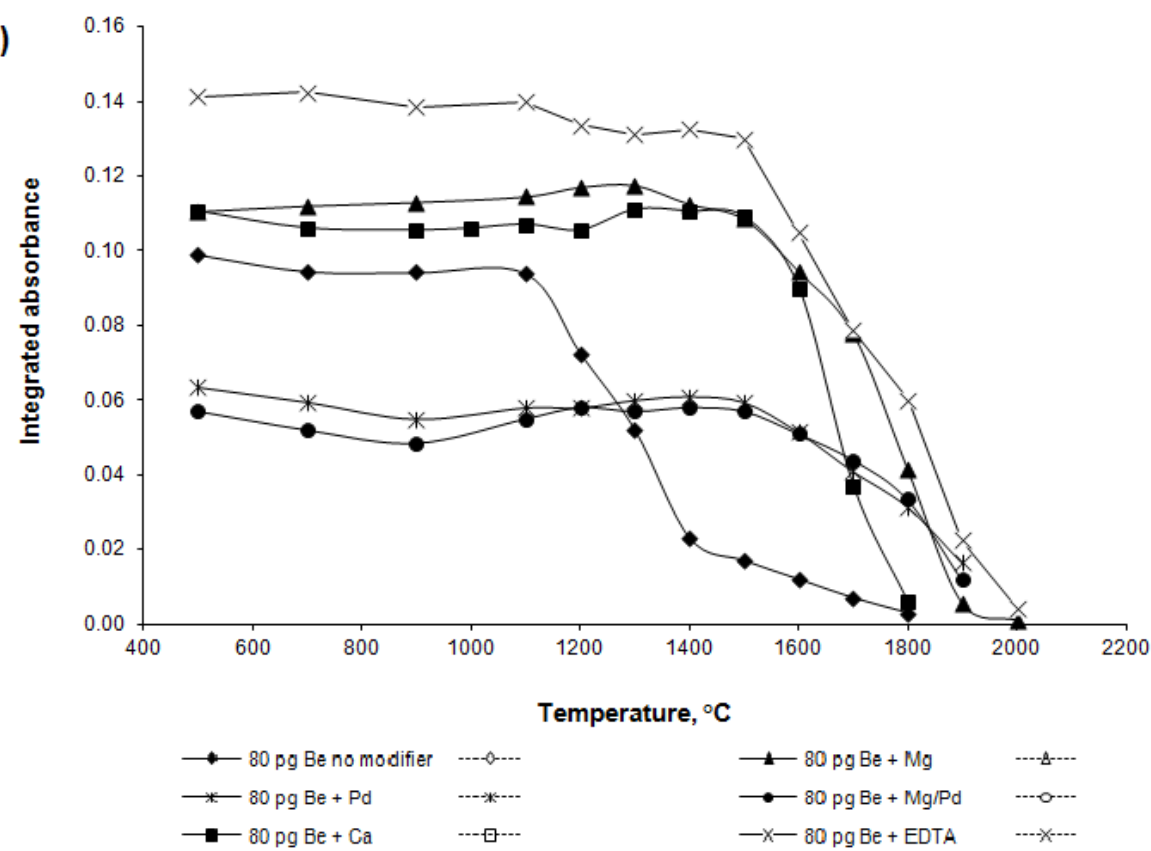

(B)

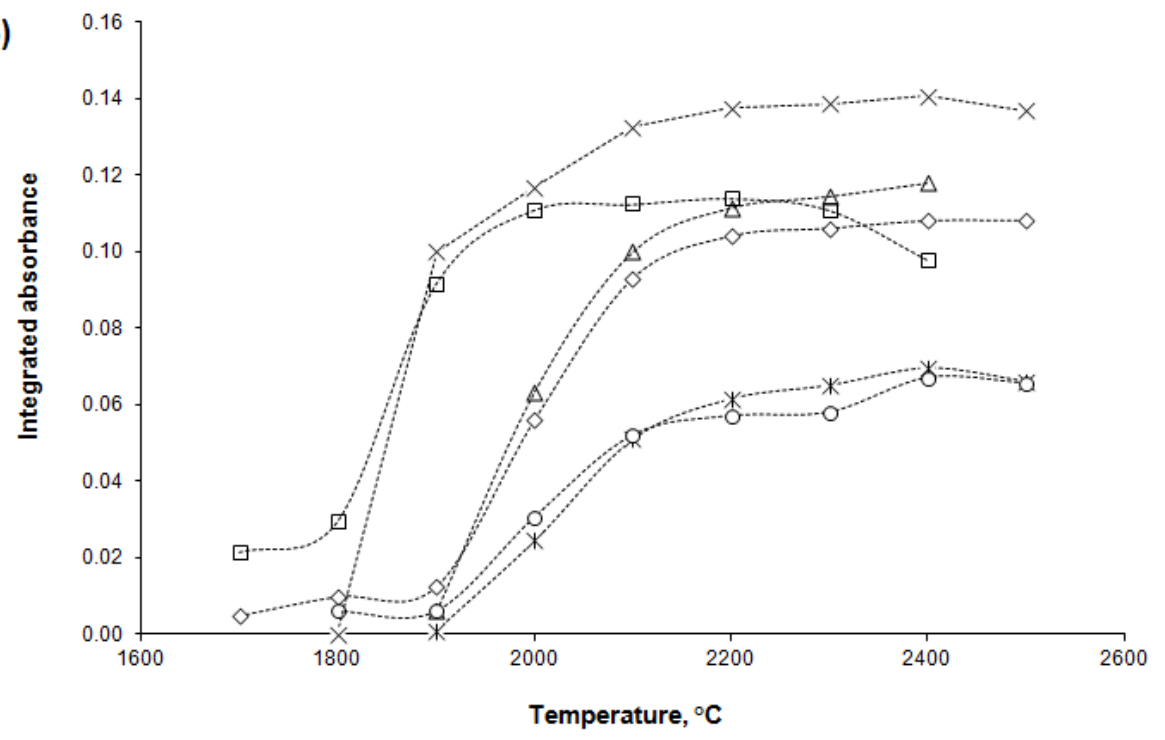

Figure 1. Pyrolysis curves (compact lines) (A) and atomization curves (broken lines) $(B)$ for $B e(80$ $\mathrm{pg}$ ) without and with chemical modification

The optimum pyrolysis temperatures selected for the used modifiers are introduced in Table 1. The optimum atomization temperature was used the same $\left(2300^{\circ} \mathrm{C}\right)$ in all cases.

Table 1. Temperature program for the determination of beryllium in waters by ETAAS

\begin{tabular}{lcccc}
\hline Step & $\begin{array}{c}\text { Temperature } \\
\left({ }^{\circ} \mathrm{C}\right)\end{array}$ & $\begin{array}{c}\text { Ramp time } \\
(\mathrm{s})\end{array}$ & $\begin{array}{c}\text { Hold time } \\
(\mathrm{s})\end{array}$ & $\begin{array}{c}\text { Ar flow } \\
\left(\mathrm{mL} \mathrm{min}^{-1}\right)\end{array}$ \\
\hline Drying & 110 & 1 & 20 & 250 \\
Drying & 130 & 5 & 30 & 250 \\
Pyrolysis & $1100^{\mathrm{a}} / 1300^{\mathrm{b}} / 1400^{\mathrm{c}}$ & 10 & 20 & 250 \\
Atomization & 2300 & 0 & 5 & 0 \\
Cleaning & 2400 & 1 & 2 & 250 \\
\hline
\end{tabular}

${ }^{a}$ measurements without the addition of any modifier; ${ }^{b}$ measurements with $\mathrm{Ca}\left(\mathrm{NO}_{3}\right)_{2}, \mathrm{Mg}\left(\mathrm{NO}_{3}\right)_{2}$ and EDTA; ${ }^{\circ}$ measurements with $\left(\mathrm{Pd}\left(\mathrm{NO}_{3}\right)_{2}\right.$ and $\mathrm{Pd}\left(\mathrm{NO}_{3}\right)_{2}+\mathrm{Mg}\left(\mathrm{NO}_{3}\right)_{2}$ 


\section{Analytical figures of merit}

Analytical characteristics of the methods with the various chemical modifiers, including characteristic mass calculated as $m_{0}=0.0044 \times 20 / a$, where $a$ is the slope of the calibration curve and sample volume is $20 \mu \mathrm{L}$, the limit of detection (LOD) calculated as $3 S D / a$, where $a$ is the slope of the calibration curve and $S D$ the standard deviation of 10 consecutive measurements of blank solutions, the limit of quantification (LOQ) calculated on the basis of 10SD/a (Currie, 1999) and precision (RSD, evaluated by ten replicate analyses of solutions containing $80 \mathrm{pg}$ of beryllium) are summarized in Table 2.

Sensitivity is increasing in order: $\mathrm{Pd}\left(\mathrm{NO}_{3}\right)_{2}+\mathrm{Mg}\left(\mathrm{NO}_{3}\right)_{2}<\mathrm{Pd}\left(\mathrm{NO}_{3}\right)_{2}<\mathrm{Ca}\left(\mathrm{NO}_{3}\right)_{2}<$ no modifier < $\mathrm{Mg}\left(\mathrm{NO}_{3}\right)_{2}<$ EDTA. Precision is increasing in order: $\mathrm{Pd}\left(\mathrm{NO}_{3}\right)_{2}<\mathrm{Pd}\left(\mathrm{NO}_{3}\right)_{2}+\mathrm{Mg}\left(\mathrm{NO}_{3}\right)_{2}<$ no modifier $<$ $\mathrm{Ca}\left(\mathrm{NO}_{3}\right)_{2}<\mathrm{Mg}\left(\mathrm{NO}_{3}\right)_{2}<$ EDTA.

Table 2. Analytical characteristics

\begin{tabular}{lccccc}
\hline Used modifier & $\mathrm{a}^{\mathrm{a}}$ & $\begin{array}{c}\mathrm{m}_{\mathrm{o}}^{\mathrm{b}} \\
(\mathrm{pg})\end{array}$ & $\begin{array}{c}\mathrm{LOD} \\
\left(\mu \mathrm{g} \mathrm{L}^{-1}\right)\end{array}$ & $\begin{array}{c}\mathrm{LOQ} \\
\left(\mu \mathrm{L}^{-1}\right)\end{array}$ & $\begin{array}{c}\mathrm{RSD} \\
(\%)\end{array}$ \\
\hline no modifier & 0.0251 & 3.5 & 0.08 & 0.25 & 4.7 \\
$\mathrm{Pd}\left(\mathrm{NO}_{3}\right)_{2}$ & 0.0137 & 6.4 & 0.09 & 0.29 & 7.2 \\
$\mathrm{Mg}\left(\mathrm{NO}_{3}\right)_{2}$ & 0.0280 & 3.1 & 0.07 & 0.22 & 3.1 \\
$\mathrm{Pd}\left(\mathrm{NO}_{3}\right)_{2}+\mathrm{Mg}\left(\mathrm{NO}_{3}\right)_{2}$ & 0.0132 & 6.7 & 0.10 & 0.32 & 5.7 \\
$\mathrm{EDTA}$ & 0.0324 & 2.7 & 0.05 & 0.18 & 2.2 \\
$\mathrm{Ca}\left(\mathrm{NO}_{3}\right)_{2}$ & 0.0232 & 3.8 & 0.07 & 0.23 & 4.3 \\
\hline
\end{tabular}

aslope of the calibration curve for Be standard solutions without and with addition of modifiers; 'b characteristic mass; LOD-Limit of detection; LOQ-Limit of quantification; RSDRelative standard deviation

\section{Determination of $\mathrm{Be}$ in waters}

Determination of Be in the CRM "Trace metals in drinking water" and in the spiked synthetic river water without the addition of any modifier and in the presence of the studied modifiers.

CRM "Trace metals in drinking water" (TMDW) with certified value of Be concentration obtained from High-Purity Standards (Charleston, Canada) was used to verify the accuracy of the method. The evaluation of beryllium was done by calibration curve method and also by standard addition method (Table 3). Relative analytical errors (in \%) were different depending on the used modifier and evaluation method. Using no modifier and standard addition method for evaluation, the analytical error for the CRM sample was relatively the same as using calibration curve method for evaluation and $\mathrm{Mg}\left(\mathrm{NO}_{3}\right)_{2}$ as the chemical modifier.

The synthetic river water was chosen as the sample with very complex matrix. For the determination of $\mathrm{Be}$ in the synthetic river water, various chemical modifiers were applied and the selection of the modifier was done. After spiking Be $\left(4 \mathrm{\mu g} \mathrm{L}^{-1}\right)$ to the sample, evaluation of beryllium was done by calibration curve method and also by standard addition method (Table 4).

Table 3. Determination of beryllium in the $\mathrm{CRM}^{\mathrm{a}}$ "Trace metals in drinking water" without the addition of any modifier and in the presence of studied modifiers

\begin{tabular}{lcccc}
\hline \multirow{2}{*}{ Modifier } & \multicolumn{4}{c}{ Determined beryllium concentration $\left(\mu \mathrm{L} \mathrm{L}^{-1}\right)$} \\
\cline { 2 - 5 } & $\mathrm{CCM}$ & $\begin{array}{c}\mathrm{E} \\
(\%)\end{array}$ & $\mathrm{SAM}$ & $\begin{array}{c}\mathrm{E} \\
(\%)\end{array}$ \\
\hline No modifier & $34.4 \pm 1.12$ & 72 & $19.3 \pm 1.39$ & 4 \\
$\mathrm{Pd}\left(\mathrm{NO}_{3}\right)_{2}$ & $26.2 \pm 2.08$ & 31 & $17.5 \pm 2.22$ & 13 \\
$\mathrm{Mg}\left(\mathrm{NO}_{3}\right)_{2}$ & $19.4 \pm 1.25$ & 3 & $19.6 \pm 1.28$ & 2 \\
$\mathrm{Pd}\left(\mathrm{NO}_{3}\right)_{2}+\mathrm{Mg}\left(\mathrm{NO}_{3}\right)_{2}$ & $22.6 \pm 2.09$ & 13 & $23.0 \pm 1.47$ & 15 \\
$\mathrm{EDTA}$ & $19.5 \pm 2.41$ & 3 & $21.0 \pm 1.57$ & 5 \\
$\mathrm{Ca}\left(\mathrm{NO}_{3}\right)_{2}$ & $18.8 \pm 0.61$ & 6 & $19.3 \pm 1.27$ & 3 \\
\hline
\end{tabular}

${ }^{a}$ certified content of beryllium: $20.0 \pm 5.0 \mu \mathrm{g} \mathrm{L}^{-1}$; CCM-Calibration curve method;

E-Relative analytical error; SAM-Standard addition method

The results in Table 4 show fundamental differences between these modifiers when they are applying for the determination of $\mathrm{Be}$ in synthetic river water by ETAAS. Recoveries were different 
depending on the used modifier and the evaluation method. Using standard addition method for evaluation without modifier, recoveries for the spiked samples were in the range $99-111 \%$. Using calibration curve method for evaluation without modifier, recoveries for the spiked synthetic river water were around $248 \%$. Using $\mathrm{Mg}\left(\mathrm{NO}_{3}\right)_{2}$ as the chemical modifier and calibration curve method for evaluation, recovery for the spiked sample of synthetic river water was $104 \%$.

Table 4. Determination of beryllium in the spiked synthetic river water $\left(4 \mu \mathrm{g} \mathrm{L}^{-1}\right)$ without the addition of any modifier and in the presence of studied modifiers

\begin{tabular}{lcccc}
\hline \multirow{2}{*}{ Modifier } & \multicolumn{4}{c}{ Determined beryllium concentration $\left(\mu \mathrm{g} \mathrm{L}^{-1}\right)$} \\
\cline { 2 - 5 } & $\mathrm{CCM}$ & $\begin{array}{c}\mathrm{R} \\
(\%)\end{array}$ & $\mathrm{SAM}$ & $\mathrm{R}$ \\
& & 248 & $4.45 \pm 0.28$ & 111 \\
\hline No modifier & $9.92 \pm 0.51$ & 174 & $4.37 \pm 0.10$ & 109 \\
$\mathrm{Pd}\left(\mathrm{NO}_{3}\right)_{2}$ & $6.97 \pm 0.18$ & 104 & $3.97 \pm 0.29$ & 99 \\
$\mathrm{Mg}\left(\mathrm{NO}_{3}\right)_{2}$ & $4.15 \pm 0.31$ & 111 & $4.02 \pm 0.24$ & 102 \\
$\mathrm{Pd}\left(\mathrm{NO}_{3}\right)_{2}+\mathrm{Mg}\left(\mathrm{NO}_{3}\right)_{2}$ & $4.45 \pm 0.07$ & 120 & $4.08 \pm 0.49$ & 102 \\
$\mathrm{EDTA}$ & $4.80 \pm 0.05$ & 103 & $4.16 \pm 0.08$ & 104 \\
$\mathrm{Ca}\left(\mathrm{NO}_{3}\right)_{2}$ & $4.11 \pm 0.12$ &
\end{tabular}

CCM-Calibration curve method; R-Recovery; SAM-Standard addition method

In spite of the fact that also EDTA seems to be the appropriate chemical modifier leading to an increased sensitivity, precision and lower LODs values (Table 2), similar accuracy (Tables 3 and 4), worst recoveries compared to $\mathrm{Mg}\left(\mathrm{NO}_{3}\right)_{2}$ (see Table 4) were observed. We have concluded that $\mathrm{Mg}$ (as the generally used "ashing aid" for pyrolysis step) is more appropriate chemical modifier, universal for all types of the studied waters. Magnesium nitrate as the modifier stabilized beryllium and inhibits the formation of the relatively volatile $\mathrm{Be}(\mathrm{OH})_{2}$. Further experiments for the determination of $\mathrm{Be}$ in tap water, synthetic river water and mineral waters and for determination of $\mathrm{Be}$ in drinking waters and waste waters were done without modifier and using $\mathrm{Mg}\left(\mathrm{NO}_{3}\right)_{2}$ as the selected chemical modifier.

\section{Determination of Be in the tap water, synthetic river water and mineral waters}

Concentrations of $\mathrm{Be}$ in the tap water and analyzed mineral waters (MWQ and MWS) were found to be $<$ LOD. In this case spiking of Be was also done. After spiking $B e\left(1 \mu \mathrm{L} \mathrm{L}^{-1}\right.$ or $\left.4 \mu \mathrm{g} \mathrm{L}^{-1}\right)$ to the tap water, synthetic river water and mineral waters, evaluation of beryllium was made by calibration curve method and also by standard addition method (Table 5). Using no modifier and standard addition method for evaluation, recoveries for the all spiked samples were in the range 95-114\%. Using $\mathrm{Mg}\left(\mathrm{NO}_{3}\right)_{2}$ as the matrix modifier, recoveries were in the range $97-113 \%$ in any case of evaluation for the all spiked mineral waters. Using calibration curve method without the use of chemical modifier very high (\%) relative analytical errors or (\%) recoveries were performed, probably because of the matrix interferences.

\section{Determination of $\mathrm{Be}$ in drinking waters and waste waters}

Drinking waters and waste waters with reference values of Be concentrations obtained from Aslab (Water Research Institute, Praque, Czech Republic) were used to verify the accuracy of the methods. Also in this case, the different methods were used for the determination of Be in the waters (measurement without the addition of any modifier and measurement with $\mathrm{Mg}\left(\mathrm{NO}_{3}\right)_{2}$ as the matrix modifier). Relative analytical errors in Be determination are shown in Table 6. Using no modifier and calibration curve method for evaluation, determined Be concentrations were around 2.5 times more compared with the reference values for the drinking waters, around 3.5 times more compared with the reference values for the waste waters. Using no modifier and standard addition method, relative analytical errors in Be determination were in the range $3-11 \%$. Using $\mathrm{Mg}\left(\mathrm{NO}_{3}\right)_{2}$ as the matrix modifier, relative analytical errors in Be determination were in the range $5-9 \%$ in any case of evaluation. 
Table 5. Determination of beryllium in the spiked tap water, synthetic river water and mineral water without the addition of any modifier and in the presence of $\mathrm{Mg}\left(\mathrm{NO}_{3}\right)_{2}$

\begin{tabular}{|c|c|c|c|c|c|c|c|c|c|}
\hline \multirow{3}{*}{ Sample } & \multirow{3}{*}{$\begin{array}{c}\mathrm{Be} \\
\text { added } \\
\left(\mu \mathrm{g} \mathrm{L}^{-1}\right)\end{array}$} & \multicolumn{8}{|c|}{ Determined beryllium concentration $\left(\mu \mathrm{g} \mathrm{L}^{-1}\right)$} \\
\hline & & \multicolumn{4}{|c|}{ No modifier } & \multicolumn{4}{|c|}{$\mathrm{Mg}\left(\mathrm{NO}_{3}\right)_{2}$} \\
\hline & & CCM & $\begin{array}{c}\mathrm{R} \\
(\%)\end{array}$ & SAM & $\begin{array}{c}R \\
(\%)\end{array}$ & CCM & $\begin{array}{c}R \\
(\%)\end{array}$ & SAM & $\begin{array}{c}R \\
(\%)\end{array}$ \\
\hline & 0 & \multicolumn{4}{|c|}{ ND } & \multicolumn{4}{|c|}{ ND } \\
\hline \multirow[t]{2}{*}{ TW } & 1 & $1.22 \pm 0.23$ & 122 & $1.14 \pm 0.15$ & 114 & $1.08 \pm 0.08$ & 108 & $1.05 \pm 0.11$ & 105 \\
\hline & 4 & $4.58 \pm 0.35$ & 115 & $4.32 \pm 0.22$ & 108 & $3.95 \pm 0.25$ & 99 & $4.28 \pm 0.31$ & 107 \\
\hline & 0 & \multicolumn{4}{|c|}{ ND } & \multicolumn{4}{|c|}{ ND } \\
\hline \multirow{2}{*}{ SRW } & 1 & $2.31 \pm 0.18$ & 231 & $0.95 \pm 0.11$ & 95 & $1.13 \pm 0.15$ & 113 & $0.99 \pm 0.23$ & 99 \\
\hline & 4 & $9.92 \pm 0.51$ & 248 & $4.45 \pm 0.28$ & 111 & $4.15 \pm 0.31$ & 104 & $3.85 \pm 0.29$ & 96 \\
\hline & 0 & \multicolumn{4}{|c|}{ ND } & \multicolumn{4}{|c|}{ ND } \\
\hline \multirow[t]{2}{*}{ MWQ } & 1 & $1.34 \pm 0.30$ & 134 & $1.10 \pm 0.15$ & 110 & $0.97 \pm 0.13$ & 97 & $0.99 \pm 0.21$ & 99 \\
\hline & 4 & $5.14 \pm 0.18$ & 129 & $3.88 \pm 0.28$ & 97 & $4.19 \pm 0.29$ & 105 & $3.92 \pm 0.17$ & 98 \\
\hline \multirow{3}{*}{ MWS } & 0 & \multicolumn{4}{|c|}{ ND } & \multicolumn{4}{|c|}{ ND } \\
\hline & 1 & $1.76 \pm 0.22$ & 176 & $1.12 \pm 0.20$ & 112 & $1.09 \pm 0.20$ & 109 & $1.03 \pm 0.19$ & 103 \\
\hline & 4 & $6.62 \pm 0.35$ & 166 & $396+014$ & 99 & $4.12 \pm 0.18$ & 103 & $3.78 \pm 0.28$ & 95 \\
\hline
\end{tabular}

CCM-Calibration curve method; R-Recovery; SAM-Standard addition method; TW-Tap water; SRWSynthetic river water; MWQ-Mineral water "Korytnica" quiet; MWS-Mineral water "Korytnica" sparkling; ND-Not detected

Table 6. Determination of beryllium in the drinking waters and waste waters without the addition of any modifier and in the presence of $\mathrm{Mg}\left(\mathrm{NO}_{3}\right)_{2}$

\begin{tabular}{|c|c|c|c|c|c|c|c|c|c|}
\hline \multirow{3}{*}{ Sample } & \multirow{3}{*}{$\begin{array}{c}\text { Reference } \\
\text { content } \\
\left(\mu \mathrm{g} \mathrm{L}^{-1}\right)\end{array}$} & \multicolumn{8}{|c|}{ Determined beryllium concentration $\left(\mu \mathrm{g} \mathrm{L}^{-1}\right)$} \\
\hline & & \multicolumn{5}{|c|}{ No modifier } & \multicolumn{2}{|c|}{$\mathrm{Mg}\left(\mathrm{NO}_{3}\right)_{2}$} & \multirow[b]{2}{*}{$\begin{array}{c}E \\
(\%)\end{array}$} \\
\hline & & $\mathrm{CCM}$ & $\begin{array}{c}E \\
(\%)\end{array}$ & SAM & $\begin{array}{c}E \\
(\%)\end{array}$ & $\mathrm{CCM}$ & $\begin{array}{c}E \\
(\%)\end{array}$ & SAM & \\
\hline DW4 & 1.57 & $4.03 \pm 0.18$ & 157 & $1.62 \pm 0.38$ & 3 & $1.67 \pm 0.12$ & 6 & $1.46 \pm 0.21$ & 7 \\
\hline DW5 & 1.67 & $4.00 \pm 0.23$ & 139 & $1.49 \pm 0.12$ & 11 & $1.79 \pm 0.27$ & 7 & $1.54 \pm 0.17$ & 8 \\
\hline WW4 & 1.52 & $4.66 \pm 0.29$ & 207 & $1.38 \pm 0.24$ & 9 & $1.66 \pm 0.18$ & 9 & $1.40 \pm 0.19$ & 8 \\
\hline WW5 & 5.00 & $17.1 \pm 0.44$ & 242 & $4.80 \pm 0.19$ & 4 & $4.55 \pm 0.15$ & 9 & $4.76 \pm 0.28$ & 5 \\
\hline
\end{tabular}

CCM-Calibration curve method; E-Relative analytical error; SAM-Standard addition method; DWDrinking water; WW-Waste water

\section{CONCLUSIONS}

The results presented in this work have confirmed the applicability of $\mathrm{Mg}\left(\mathrm{NO}_{3}\right)_{2}$ as the chemical matrix modifier for the determination of Be in the different types of waters by ETAAS. Magnesium nitrate as the modifier stabilized beryllium and inhibits the formation of the relatively volatile $\mathrm{Be}(\mathrm{OH})_{2}$. In this case, both evaluation methods (calibration curve method and standard addition method) can be used with satisfactory result. Sensitivity and precision are increased compared with the determination without the addition of any modifier. For the determination of $\mathrm{Be}$ in natural waters without modifier, the evaluation of a standard addition method is necessary. The described method using $\mathrm{Mg}\left(\mathrm{NO}_{3}\right)_{2}$ as a matrix modifier can be used for rapid and reliable determination of $\mathrm{Be}$ in different types of waters (such as tap, river, mineral and waste waters).

\section{ACKNOWLEDGEMENTS}

This work was financially supported by the Scientific Grant Agency of the Ministry of Education of the Slovak Republic VEGA/1/0430/08, the Slovak-German Scientific Project DAAD No. 13/2004 and the Slovak Research and Development Agency No. VVCE-0070-07. 


\section{REFERENCES}

Afkhami A., Madrakain T., Assl A.A. and Sehhat A.A., (2001), Solid phase extraction flame atomic absorption spectrometric determination of ultra-trace beryllium, Anal. Chim. Acta, 437, 17-22.

Amin A.S., (2001), Utilization of solid phase spectrophotometry for determination of trace amounts of beryllium in natural water, Anal. Chim. Acta, 437, 265-272.

Burguera J.L., Burguera M., Rondón C. and Carrero P., (1999), Semi-permanent lutetium modifier for the determination of beryllium in urine by electrothermal atomic absorption spectrometry, Spectrochim. Acta, Part B, 54, 1743-1753.

Burguera J.L., Burguera M., Rondon C., Carrero P., Brunetto M.R. and Petit de Peña Y., (2000), Determination of beryllium in natural and waste waters using on-line flow-injection preconcentration by precipitation/dissolution for electrothermal atomic absorption spectrometry, Talanta, 52, 27-37.

Castro M.A., Robles L.C., Lumbreras J.M., De Celis B., Aller A.J. and Littlejohn D., (2009), Determination of beryllium by electrothermal atomic absorption spectrometry using tungsten surfaces and zirconium modifier, Anal. Chim. Acta, 636, 158-162.

Černohorský T. and Kotrlý S., (1995), Determination of beryllium in drinking and waste water by tungsten furnace atomic absorption spectrometry, J. Anal. At. Spectrom., 10, 155-160.

Chakraborti D., Adams F., Van Mol W. and Irgolic K.J., (1987), Determination of trace metals in natural waters at nanogram per liter levels by electrothermal atomic absorption spectrometry after extraction with sodium diethyldithiocarbamate, Anal. Chim. Acta, 196, 23-31.

Chamsaz M., Arbabzavar M.H., Heidari T., Hajinia A. and Salehi T., (2010), Spectrophotometric determination of trace amounts of beryllium in natural water using mean centering of ratio spectra and partial least squares regression, Asia J. Chem., 22, 4717-4726.

Currie L.A., (1999), Nomenclature in evaluation of analytical methods including detection and quantification capabilities (IUPAC Recommendations 1995), Anal. Chim. Acta, 391, 105-126.

Fangruo L., Xiaoying L. and Mohui W., (1990), The study of modifiers for the determination of beryllium by graphite furnace atomic absorption spectrometry, At. Spectrosc., 11, 78-82.

Forrer R., Gautschi K. and Lutz H., (2001a), Simultaneous measurement of the trace elements Al, As, B, $\mathrm{Be}, \mathrm{Cd}, \mathrm{Co}, \mathrm{Cu}, \mathrm{Fe}, \mathrm{Li}, \mathrm{Mn}, \mathrm{Mo}, \mathrm{Ni}, \mathrm{Rb}, \mathrm{Se}, \mathrm{Sr}$, and $\mathrm{Zn}$ in human serum and their reference ranges by ICP-MS, Biol. Trace Elem. Res., 80, 77-93.

Forrer R., Wenker C., Gautschi K. and Lutz H., (2001b), Concentration of 17 trace elements in serum and whole blood of plains viscachas (Lagostomus maximus) by ICP-MS, their ranges, and their relation to cataract, Biol. Trace Elem. Res., 81, 47-62.

Hiraide M., Ishikawa K., Chen Z.S. and Kawaguchi H., (1994), Coprecipitation with metal-hydroxides for the determination of beryllium in sea water by graphite furnace atomic absorption spectrometry, Microchim. Acta, 117, 7-13.

Jiang C.Q. and He F., (2003), Spectrofluorimetric determination of trace amounts of beryllium in mineral water and human's hair, Spectrochim. Acta, Part A, 59, 1321-1328.

Korečková-Sysalová J., (1997), Determination of beryllium in natural waters using atomic absorption spectrometry with tantalum-coated graphite tube, Int. J. Environ. Anal. Chem., 68, 397-404.

Kubová J., Nevoral V. and Streško V., (1994), Determination of beryllium trace contents in mineral waters after preconcentration on a chelating ion-exchanger, Fresenius J. Anal. Chem., 348, 287-290.

Lytle D.A., Schock M.R., Dues N.R. and Doerger J.U., (1993), Determining beryllium in drinking water by graphite furnace atomic absorption spectroscopy, J. Am. Water Works Assoc., 85, 77-83.

Madrakian T., Afkhami A., Borazjani M. and Bahram M., (2005), Partial least-square regression for the simultaneous determination of aluminium and beryllium in geochemical samples using xylenol orange, Spectrochim. Acta, Part A, 61, 2988-2994.

McAlister D.R. and Horwitz E.P., (2005), A method for the separation of beryllium from spectral interfering elements in inductively coupled plasma-atomic emission spectroscopic analysis, Talanta, 67, 873879.

Nakamura T., Oka H., Ishii M. and Sato J., (1994), Direct atomization atomic absorption spectrometric determination of $\mathrm{Be}, \mathrm{Cr}, \mathrm{Co}, \mathrm{Ni}, \mathrm{Cu}, \mathrm{Cd}$, and $\mathrm{Pb}$ in water with zirconium hydroxide coprecipitation, Analyst, 119, 1397-1401.

Okamoto Y., Nakata F., Obata Y., Takahashi T., Fujiwara T. and Yamamoto M., (2002), Optimisation of on-line liquid-liquid extraction for beryllium determination by inductively coupled plasma atomic emission spectrometry (ICP-AES), J. Anal. At. Spectrom., 17, 277-279. 
Peng H.W. and Kuo M.S., (2000), Determination of trace amounts of beryllium(II) in drinking water and of beryllium vapor in air by graphite-furnace atomic absorption spectrophotometry using acetylacetone as a chelating agent, Anal. Sci., 16, 157-161.

Rama M.J.R., Medina A.R. and Díaz A.M., (2004), Implementation of flow-through multi-sensors with bead injection spectroscopy: flourimetric renewable surface biparameter sensor for determination of beryllium and aluminium, Talanta, 62, 879-886.

Recknagel S., Chrissafidou A., Albert D., Rösick U. and Brätter P., (1997), Determination of beryllium in the primary cooling water of the BER II research reactor by inductively coupled plasma optical emission spectrometry and zeeman electrothermal atomic absorption spectrometry, J. Anal. At. Spectrom., 12, 1021-1025.

Robles L.C. and Aller A.J., (1994), Preconcentration of beryllium on the outer membrane of Escherichiacoli and pseudomonas-putida prior to determination by electrothermal atomic absorption spectrometry, J. Anal. At. Spectrom., 9, 871-879.

Shan X.-Q., Yian Z. and Ni Z.-M., (1989), Determination of beryllium in urine by graphite furnace atomic absorption spectrometry, Anal. Chim. Acta, 217, 271-280.

Singh H.B., Agnihorti N.K. and Singh V.K., (1998), Determination of trace amounts of beryllium using derivative spectrophotometry in non-ionic micellar medium, Talanta, 47, 1287-1296.

Sun X., (1999), Determination of beryllium in river water by graphite furnace atomic absorption spectrometry, Spectrosc. Spectral Anal., 19, 607-609.

Suvardhan K., Kumar K.S., Rekha D., Jayaraj B., Naidu G.K. and Chiranjeevi P., (2006), Preconcentration and solid-phase extraction of beryllium, lead, nickel, and bismuth from various water samples using 2-propylpiperidine-1-carbodithioate with flame atomic absorption spectrometry (FAAS), Talanta, 68, 735-740.

Taylor T.P., Ding M., Ehler D.S., Foreman T.M., Kasuba J.P. and Sauer N.N., (2003), Beryllium in the environment: A review, J. Environ. Sci. Health., Part A, 38, 439-469.

Vanhoe H., Vandecasteele C., Desmet B. and Dams R., (1988), Determination of beryllium in liquid and solid waste samples by flame and furnace AAS, J. Anal. At. Spectrom., 3, 703-707.

Wen B., Shan X.Q. and Xu S.G., (2000), Preconcentration of trace elements in sea water with 8hydroxyquinoline immobilized polyacrylonitrile hollow fiber membrane for determination by inductively coupled plasma-mass spectrometry, Int. J. Environ. Anal. Chem., 77, 95-109.

Wu Y.L., Hu B., Peng T.Y. and Jiang Z.C., (2001), Low-temperature volatilization of Be acetylacetonate for sample introduction in ETV-ICP-AES, Anal. Chim. Acta, 439, 153-158.

Yamini Y., Hassan J., Mohandesi R. and Bahramifar N., (2002), Preconcentration of trace amounts of beryllium in water samples on octadecyl silica cartridges modified by quinalizarine and its determination with atomic absorption spectrometry, Talanta, 56, 375-381.

Yang W-M. and Ni Z-M., (1994), The possibility of standardless analysis in graphite furnace atomic absorption spectrometry - determination of beryllium in environmental and biological samples, Spectrochim. Acta, Part B, 49, 1067-1079. 